\title{
El difícil camino de la legalidad. Vigencia y validez de los resquicios legales y su aplicación en el programa económico de Salvador Allende. Chile, 1970-1973
}

The difficult Path of Legality. The Debate on the Validity of Legal Loopholes and their Application in Salvador Allende's Economic Program. Chile, 1970-1973 Le difficile chemin de la légalité. Vigueur et validité des vides juridiques et son application dans le programme économiques de Salvador Allende. Chili, 1970-1973

\section{Alejandro Luis Polanco Ramírez}

\section{(2) OpenEdition}

\section{Journals}

Edición electrónica

URL: http://journals.openedition.org/rhj/6713

DOI: $10.4000 /$ rhj.6713

ISSN: 0719-4153

Editor

ACTO Editores Ltda

Referencia electrónica

Alejandro Luis Polanco Ramírez, «El difícil camino de la legalidad. Vigencia y validez de los resquicios legales y su aplicación en el programa económico de Salvador Allende. Chile, 1970-1973 ", Revista Historia y Justicia [En línea], 1 | 2013, Publicado el 30 octubre 2013, consultado el 01 diciembre 2020. URL : http://journals.openedition.org/rhj/6713 ; DOI : https://doi.org/10.4000/rhj.6713 


\title{
EL DIFÍCIL CAMINO DE LA LEGALIDAD. VIGENCIA Y VALIDEZ DE LOS RESQUICIOS LEGALES Y SU APLICACIÓN EN EL PROGRAMA ECONÓMICO DE SALVADOR AlLENDE. CHILE, 1970-1973
}

\author{
Alejandro Luis POLANCO RAMÍREZ (*)
}

\begin{abstract}
El programa del Presidente Salvador Allende Gossens fue bloqueado desde un inicio por el parlamento chileno. Para cumplir su programa manteniéndose dentro de la legalidad, se encargó al Profesor de Derecho Eduardo Novoa Monreal descubrir normas vigentes (en un sistema jurídico en descomposición) que fuesen útiles para dicho fin, apoyado en una fina lógica de positivismo jurídico. La derecha política y los tribunales de justicia se mostraron hostiles a esta solución y polemizaron con ella. Esta dura polémica finalmente contribuyó a deslegitimar al gobierno y a justificar el golpe militar de Augusto Pinochet Ugarte.
\end{abstract}

Palabras Clave : Chile, Siglo XX, política, derecho, resquicios legales

The difficult Path of Legality. The Debate on the Validity of Legal

Loopholes and their Application in Salvador Allende's Economic Program. Chile, 1970-1973

The Chilean parliament blocked from the beginning Salvador Allende's economic program.

Trying to achieve his program through legal means, but in the context of a decomposing legal system, Allende commissioned Eduardo Novoa Monreal, an eminent Professor of Law, to find, within the existing legal order, the norms that would allow the President to achieve his program through the use of a refined logic of legal positivism. The conservative political parties and the Chilean courts of justice were hostile to these mechanisms and rejected this solution. In the end, this controversy contributed to delegitimize the government and to justify Pinochet's military coup.

Keywords : Chile, XXth century, Politic, Law, Legal Loopholes
Le difficile chemin de la légalité. Vigueur et validité des vides juridiques et son application dans le programme économiques de Salvador Allende. Chili, 1970-1973

Le programme du président Salvador Allende Gossens a été bloqué depuis le début par le parlement chilien. Afin d'accomplir son programme économique dans la légalité, il demanda au professeur de droit, Eduardo Novoa Monreal, de chercher des normes en vigueur -au sein d'un système juridique en décomposition-qui puissent être utiles à cette fin, appuyées par une subtile logique de positivisme juridique. La droite politique et les tribunaux de justice se montrèrent hostiles à cette solution et entrèrent en polémique. Finalement, cette polémique contribua à délégitimer le gouvernement et à justifier le coup d'état militaire de Augusto Pinochet Ugarte.

Mots clé : Chile, XX siècle, politique, droit, vides juridiques

Recibido : 30 de mayo de 2013 / Aceptado : 10 de octubre de 2013

(*) Licenciado en Ciencias Jurídicas y Sociales y Abogado (Universidad de Chile). Investigador independiente. Santiago, Chile. alejandropolancoramirez@gmail.com 


\title{
El difícil camino de la legalidad. Vigencia y validez de los resquicios legales y su aplicación en el programa económico de Salvador Allende. Chile, 1970-1973
}

\author{
Alejandro Luis POLANCO RAMÍREZ
}

\section{Introducción}

Como señala Eduardo Novoa Monreal -autor intelectual de los resquicios- en un libro editado en 1992 por una editorial poco conocida ${ }^{1}$, que precisamente lleva como título el tema que nos ocupa, para el chileno de hoy (y hablaba Novoa de 20 años atrás) poco significa la expresión "resquicios legales". En derecho suele discutirse en teoría de las normas la diferencia entre forma y contenido de ellas, y en ese mismo sentido, creo que, independiente de lo que signifique realmente "resquicio legal", la frase es polémica en sí misma e invita a la discusión, a la indagación, y al recuerdo.

Los que tengan más edad y sean bien informados posiblemente recordarán que apareció en el gobierno del Presidente Salvador Allende dentro del ambiente de tosca confrontación política entre el gobierno y sus detractores como uno de los tantos aspectos conflictivos que de diversas maneras se pusieron en el debate público. Pero creo que la mayoría de la gente, más joven o poco informada, se hará la idea de algo extraño, vago, pero que tiende a relacionarse con una "leguleyada" de mala clase ${ }^{2}$ o un ardid de ésos comunes de los poco estimados abogados. Pero no es ése el sentido que en su época se le atribuyó, y al cual me quiero referir en estas líneas, sino a uno de los aspectos fundamentales del programa del presidente Allende: la utilización de la legislación vigente, tal vez poco conocida por el ciudadano común e incluso por los mismos abogados y juristas de la época, pero creemos absolutamente vigente, y en primera instancia (no obstante las conclusiones a las que llegaremos), útiles para una primera fase del programa del presidente socialista.

Tal revuelo provocó la aplicación de tales disposiciones legales que en su momento fue el núcleo de un áspero debate entre el gobierno -a través del Profesor Novoa e

\footnotetext{
${ }^{1}$ Novoa Monreal, Eduardo, Los resquicios legales. Un ejercicio de lógica jurídica, Editorial Bat, Santiago, 1992.
}

${ }^{2}$ Novoa Monreal, E., Los Resquicios, Op.Cit, p. 108. 
incluso del mismo Presidente Allende- y la oposición, que, creemos, y así veremos en su momento, fue una de los mejores excusas del golpismo para derribar al gobierno; En efecto, el golpismo se apoyó decididamente en el cuestionamiento, de parte de los organismos jurisdiccionales y algunos de los más importantes doctrineros (es decir el cuerpo jurídico de este país), al uso que de dicha legislación hizo el gobierno de Allende, acusándolo de vulnerar la constitución, la legalidad, el estado de derecho e incluso "la noble tradición jurídica chilena"3.

Eduardo Novoa da una connotación política a este fracaso, provocado por las tendencias reaccionarias a que respondía sobre todo el poder judicial y la derecha chilena, que por convicción e interés pueden y saben manipular entre otras cosas el ordenamiento jurídico. Muchos estudios políticos han llegado a igual conclusión (por ejemplo, los de Corvalán o Altamirano). Otros, de una manera abierta con argumentos que apelan a la tradición ${ }^{4} \mathrm{o}$, sin mayor base, parece que le dan la razón a las tesis de la derecha ${ }^{5}$, pero, me parece que en general se ha descuidado el aspecto jurídico del tema, optando por razones más bien políticas, que sin dejar de ser las de mayor importancia y que finalmente explican los hechos, pasan por alto cuestiones fundamentales para una explicación completa de un fenómeno que es también (y en grado fundamental) jurídico.

Es decir, creo que tanto el planteamiento del problema por los personeros de la Unidad Popular como su estudio posterior, han descuido el tema jurídico, ya sea desde perspectivas de auténtica sociología jurídica o de otras relacionadas a la teoría general del derecho. Estas perspectivas pueden resultar valiosas para apreciar los fundamentos reales de los resquicios legales como derecho vigente, y para evaluar si aquello era útil como táctica para avanzar hacia el socialismo. También, en el tiempo actual, estas perspectivas son útiles para valorar una experiencia honesta y de profundas raíces éticas y de compromiso por Chile, pero que, como era previsible, fracasó.

Por otro lado, es justo decir que, respecto a los cuestionamientos que yo hago, Eduardo Novoa en más de una ocasión mostró tener claridad; pero, probablemente por las circunstancias, no pudo ahondar en ellos ni desandar lo caminado.

En fin, espero, dentro de lo posible, y advirtiendo que mis conclusiones son provisionales, orientarme hacia una perspectiva histórico-jurídica del problema, dejando de lado algunas cuestiones conexas al tema de los resquicios, como las acusaciones constitucionales que en parte motivaron, o el proyecto Hamilton- Fuentealba, por ser, más que jurídico, políticos.

\footnotetext{
${ }^{3}$ Brahm García, Enrique, "La perversión de la cultura jurídica chilena durante el gobierno de la Unidad Popular. Resquicios legales y derecho de propiedad", Revista Chilena de Historia del Derecho, Santiago no 18 , 2000 , p. 346.

4 Bravo, Bernardino, "Presidente y Estado de Derecho en Chile", Revista Derecho y Jurisprudencia, Santiago, Tomo XC, 1993, p. 86.

${ }^{5}$ Loveman, Brian y Lira, Elizabeth, Las Ardientes Cenizas del olvido. Vía Chilena de reconciliación Política,19321994, LOM, Santiago, 2000, p. 342.
} 


\section{La época: juristas y cambio social}

Resulta problemático comprender el conflicto suscitado por la aplicación de los así llamados resquicios. Por un lado, es complejo entender que se niegue validez a un derecho vigente. Por otro, y esto es tal vez más complejo aún, es difícil comprender el intento de apoyarse en el derecho con fines de cambio social o, francamente, al menos en lo discursivo, revolucionarios.

El planteamiento general de la Unidad Popular, tal como lo resume Rodrigo Baño ${ }^{6}$, es que mediante el uso de la institucionalidad jurídico-política vigente era posible llevar a cabo un proceso acelerado y radical de cambios económicos y sociales, que culminasen con la instauración de un régimen de tipo socialista. A decir de los entendidos, más objetivos y menos nostálgicos, en general esta posibilidad de transformación, ni más ni menos que de una sociedad de un determinado tipo en otra, a través de la vía pacifica, se encontró y se encuentra bastante poco desarrollada, excepto por la estrategia eurocomunista, que a no ser por la exigencia de mayorías inmensamente grandes que harían a la burguesía retroceder en sus intentos violentos, tampoco tiene elementos teóricos demasiado definidos. Chile también aspiraba a algo parecido, es decir, tener mayorías que permitieran al gobierno, a través del mecanismo constitucional, ser inatacable y consolidarse.

Más allá de este desarrollo teóricamente limitado, la viabilidad del proyecto político de la Unidad Popular se afirmaba sustancialmente en la fuerza de la legitimidad legal del poder, en el caso chileno. Adquiría consideración de realismo político, al contrario de las conclusiones de buena e importante parte de la izquierda revolucionaria latinoamericana, la consideración de que era improbable hacer algo que estuviera, en Chile, fuera de la ley. La formalización temprana del conflicto social y del proceso político, a partir de la actividad de los partidos políticos, contribuyó, y tal vez todavía contribuya todavía hoy, a la aceptación generalizada en la sociedad chilena de este "legalismo" político. Al revés de lo que podría pensarse, adecuándose a la ley, era difícil, por no decir muy improbable, que uno fuese desplazado por la fuerza. Desde el principio la estrategia comunicacional del presidente Allende fue ostentar de la legalidad de su régimen y de su programa, resaltando el carácter legal y legalista de su gobierno y de cada una de las acciones que el gobierno emprendía.

Los juristas, y la academia legal, no escaparon al impulso de la época de cambios sociales de la cual el gobierno del Presidente Allende fue sólo una culminación, y comenzaron, a su vez, a cuestionar las relaciones entre derecho y cambio social, entre derecho y procesos democráticos. Como en toda la sociedad chilena, los juristas se cuestionaron acerca de cuál era la mejor conclusión. Si el derecho debe seguir su camino y no impulsar los cambios sociales, o si debe ser un agente impulsor,

\footnotetext{
${ }^{6}$ Baño, Rodrigo y Flisfisch, Ángel, "Aspectos Institucionales en el colapso de la Unidad Popular y la Democracia Chilena”, Documento de Trabajo, FLACSO-Chile, Santiago, no 342, 1987, p. 15-19.
} 
determinante y dinámico en esos cambios. Fue un importante y nutrido debate de la academia legal.

Si bien éste no es un tema nuevo, y según Máximo Pacheco es posible ya rastrearlo en el pasado hasta en las posiciones de Savigny y Von Ihering 7 , fue en la época en que nos situamos (décadas del 60-70 del siglo XX), siguiendo a Lucas Sierra, un tema de urgente actualidad, para el cual los juristas interesados tenían percepciones decididas y claras ${ }^{8}$. Caminando un poco a contracorriente de la opinión de sociólogos y economistas de la época (cuyo lenguaje y opiniones reinaban), varios juristas de profesión, dedicados al ejercicio de la abogacía y a labores de dogmática jurídica, ingresaron a la discusión y optaron por dejar atrás el prejuicio de que al derecho no le corresponde ningún papel en el cambio social ${ }^{9}$. El jurista típico estaba preocupado no del mercado, como hoy (modelo seguido de los estudios norteamericanos); al contrario, una gran parte de ellos sostenía posiciones y entendía su profesión (por lo menos en lo relacionado con el frente en el que tal discusión se desarrollaba, la academia legal y la enseñanza del derecho) como ligada al presente y al futuro de un país con necesidades de cambio. La opinión de Máximo Pacheco, es decidora del ambiente de esos años:

"El jurista tiene, hoy mas que nunca, el deber de exigir que se subsanen las anomalías del ordenamiento jurídico y que se modernice la legislación, adaptándola a las exigencias sociales y a las condiciones históricas, de manera que responda a los imperativos de justicia."

En círculos de importantes profesionales existía una incomodidad con el derecho y un afán por superar los estrechos límites en que se había petrificado, situación que lo había convertido más que en una herramienta de desarrollo acorde con una sociedad democrática que vivía profundas transformaciones, en un verdadero "obstáculo" a tales cambios. Sin duda el jurista más representativo, en sus preocupaciones académicas y en su actuar político, de aquel ánimo que orientaba a importantes juristas de esa época, fue el Profesor Eduardo Novoa Monreal, asesor Ad-Honorem del Presidente Allende y autor intelectual de los "resquicios legales". En su libro de 1975, cuando sufría del exilio, Novoa escribe una de sus obras más famosas, titulada "El derecho como obstáculo al cambio social", donde señala:

"el derecho debe ajustarse al proyecto concreto de vida social que anima a cada sociedad determinada en un momento histórico dado. El mal actual es que esto no se

\footnotetext{
${ }^{7}$ Pacheco, Máximo, Teoría del Derecho, Editorial Jurídica de Chile, Santiago, 1994, p. 294.

8 Sierra Iribarne, Lucas, "Derecho, cambio social y juristas en Chile: de la estridencia de los 60 al silencio de hoy", Documento de trabajo, SELA Yniversity, p. 2, http://digitalcommons.law.yale.edu/cgi/viewcontent.cgi?article=1012\&context=yls sela, consultado el 17 mayo 2013. 9 Trabajos sobre el tema de actores del espectro jurídico chileno de la época tan importantes como Eugenio Velasco Letelier, Francisco Cumplido, Enrique Silva Cimma, Gonzalo Figueroa o el mismo profesor Pacheco quedan como testimonio de un periodo que hoy puede parecer legendario.

10 Pacheco, M., Teoría, Op. Cit., p. 544.
} 
ha cumplido por lo que nos encontramos en presencia de un derecho obsoleto que el conservatismo de los juristas es incapaz de advertir y, mucho menos, de remover."11

Esta actitud de los juristas de avanzada (no necesariamente marxistas, ni de izquierda), representado fielmente en el pensamiento y la obra del Profesor Novoa, nos da muchas claves que permiten entender la lógica del proceso político chileno de aquella época, la búsqueda de la legalidad, la estrategia de la legalidad, la verdadera obstinación de cumplir el programa de gobierno dentro de aquellos márgenes y la aparición de estrategias jurídico-políticas basadas en teorías jurídicas aprendidas de los pensadores jurídicos más prestigiosos de la época. Creemos que detenernos a escribir dos palabras sobre la vida, obra y pensamiento de Eduardo Novoa Monreal es útil y necesario para entender el contexto del problema y, específicamente, el problema concreto de los resquicios.

\section{Eduardo Novoa Monreal, autor intelectual de los resquicios: su pensamiento jurídico-social}

Como venimos diciendo, Eduardo Novoa Monreal se hizo conocido, y lo es aún, por la creación (o mejor dicho, en sus propias palabras, por el "descubrimiento") de los resquicios legales. No obstante, la personalidad de Novoa es interesante por sí misma. Analizando su vida y obra nos encontramos con un jurista de excepción, autor de obras y aproximaciones jurídico-penales que fueron estudiadas, en su tiempo y aún hoy, en universidades chilenas y extranjeras. Fue admirado y respetado por sus alumnos y discípulos, colegas o incluso por personas extrañas al mundo del derecho, quienes reconocieron en él a un ser humano consecuente y honesto, dueño de un gran aplomo $\mathrm{y}$ fortaleza.

Pero también el nombre de Eduardo Novoa crea escozor, todavía hoy, en ciertos sectores, y uno tan grande, como fueron las diferencias y oposiciones que le manifestaron no sólo sus adversarios políticos, sino también sus colegas juristas y profesores de derecho, e incluso, penalistas muy cercanos. Su amigo y colega, el importante criminólogo argentino Roberto Bergalli Russo, en un escrito laudatorio con ocasión de su fallecimiento, publicado en El Mercurio de Santiago de Chile del 26 de abril de 2006, cita un acto donde un abogado, colega de Novoa, se expresa con notable poco recato ante su reciente muerte:

"En cambio, la sabiduría requiere de condiciones éticas que don Eduardo conoció por aproximación muy remota. (Baste sólo citar los famosos resquicios legales para robar predios). No estoy tan seguro que el señor Novoa Monreal merezca algún

\footnotetext{
${ }^{11}$ Novoa Monreal Eduardo, El Derecho como obstáculo al cambio social, Editorial siglo XX, Ciudad de México, 1975, p. 14.
} 
recordatorio especial, más allá de ponerlo como ejemplo de lo que no se debe hacer como abogado." 12

En otra ocasión fue catalogado por un colega y académico de la Universidad de Chile, aunque, sin mencionarlo, pero en clara alusión, en relación a la aplicación de los resquicios legales y la vía chilena al socialismo como un "sedicente iuspublicista de ultima hora" que facilitó la requisición de propiedad privada ${ }^{13}$.

También, eso sí, reconoce Bergalli en el mismo diario, se realizaron comentarios elogiosos a su calidad académica, profesional y personal. Dice Bergalli:

"La personalidad de Eduardo Novoa Monreal fue así vista, tan contradictoriamente como ahora lo es desde Chile, sin recato alguno por sus críticos y admiradores, después de su fallecimiento. Más este aspecto, sin dejar de ser importante a la hora de evaluar sus actuaciones sus obras, lo que hace es destacar que su paso por la vida profesional y pública no fue intrascendente."14

¿Quién es y qué pensaba Eduardo Novoa Monreal? Como señala Bergalli, este hombre, dueño de una ética "absoluta y vital", también tuvo una vida caracterizada por la vitalidad y las convicciones absolutas.

Mal podríamos reseñar su vida en estas breves líneas y todo cuanto digamos puede ser insuficiente. Sencillamente es un personaje fundamental del siglo XX en Chile.

Eduardo Novoa Monreal nace en 1916, en Arica. Su padre era también abogado. Es educado en Santiago, en el Liceo Alemán. Si bien ingresa a estudiar derecho a la Universidad Católica de Chile, finaliza sus estudios en la Universidad de Chile. Aunque siempre se consideró fundamentalmente un práctico, destaca como teórico desde su tesis de licenciatura en derecho en la Universidad de Chile, que versó sobre derecho penal ("Teoría del Consentimiento en la Víctima") y fue aprobada con la más alta calificación $^{15}$. Se titula de abogado en 1940, desarrollando la mayor parte de su actividad profesional en el Consejo de Defensa del Estado, entidad a la que ingresa en 1937, en el más bajo grado del escalafón de empleados, hasta llegar a ser su presidente en el año 1970. Se desempeña como ayudante de derecho civil y penal en la Universidad Católica de Chile. También es consejero general del Colegio de Abogados de Chile, cargo al que renuncia en 1952 por discrepancias profundas con el organismo en lo relativo a las reglas éticas que deben exigirse a los abogados en el ejercicio de la profesión.

Aprueba el examen para ser profesor extraordinario de derecho penal en la Universidad de Chile con un trabajo sobre elementos del delito en 1952, y

\footnotetext{
12 Bergalli, Roberto, "Una ética absoluta y vital. Eduardo Novoa Monreal (1916-2006)", Nueva doctrina Penal, Ediciones del puerto, Buenos Aires, no 2006/A, 2006, p. 10.005.

13 Soto Kloss, Eduardo, "La Competencia contencioso administrativa de los tribunales ordinarios de justicia”, Revista Chilena de Derecho, Santiago, vol. 1,1974, p. 356.

14 Bergalli, R., "Una Ética”, Op. Cit., p. 1.006.

15 Villalonga, Cristian, Revolución y Ley. La Teoría Critica del Derecho en Eduardo Novoa Monreal, Editorial Globo, Santiago, 2008, p. 24.
} 
posteriormente gana por concurso la cátedra de derecho penal como profesor ordinario, en 1965. Es nombrado profesor de Teoría General del derecho en la Universidad de Chile en 1970.

Paralelamente a su carrera académica, en 1963 es designado secretario de la Comisión para la Redacción del Código Penal Tipo para Latinoamérica, proyecto que busca la unificación y coherencia de las legislaciones penales de los países latinoamericanos. Esta iniciativa es un impulso prácticamente personal de Novoa, tanto en su creación como en sus resultados.

Entre sus varias membresías académicas nacionales e internacionales ${ }^{16}$, en 1968 es nombrado Académico de número de la Academia de Ciencias Sociales Políticas y Morales del Instituto de Chile ${ }^{17}$, la que abandona definitivamente en 1987, en plena dictadura, por la falta de pluralismo entre los académicos y una inadecuada forma de elección de los miembros ${ }^{18}$.

Además de ser uno de los más importantes teóricos del derecho penal en Latinoamérica, descuella como litigante realizando recordados alegatos de altísimo nivel y esforzándose por el desarrollo y la desmitificación del derecho ${ }^{19}$. Recordada es su petición de extradición del criminal nazi Walter Rauff, que da cuenta de su compromiso con las víctimas de la injusticia y que introduce en Chile la noción de imprescriptibilidad de los delitos de lesa humanidad según el derecho internacional ${ }^{20}$.

Eduardo Novoa es considerado el principal jurista de la Unidad Popular. Aunque a inicios de su vida académica y política se le puede identificar como un jurista seguidor del derecho natural (un iusnaturalismo clásico de matriz tomista, adquirido según Villalonga en sus años de estudiante en la Universidad Católica ${ }^{21}$ ) y como una persona cercana al social cristianismo (estuvo vinculado por mucho tiempo a la revista Mensaje

\footnotetext{
16 Entre 1959 y 1971 será Presidente del Instituto de Ciencias Penales de Chile; en 1963 recibirá la membresía honoraria de la Academia Mexicana de Ciencias Penales; en 1965 será designado miembro del consejo directivo de la Asociación Internacional de Derecho Penal; en 1966 se le nombrará representante por Chile de la sociedad Internacional de Criminología; entre 1969 y 1973 será consejero de la Editorial Jurídica de Chile-Andrés Bello en representación de la Universidad de Chile, entre muchos otros cargos del más alto nivel.

${ }^{17}$ Su discurso de incorporación a esta entidad versará sobre un tema que cruzará toda la carrera académica y profesional de Novoa, "La Renovación del Derecho".

18 Ver Bergalli, R., "Una Ética”, Op. Cit., p. 1.012.

${ }^{19}$ Dentro de los más importantes trabajos teóricos de crítica al derecho, podemos mencionar, sólo a título de ejemplo: "Sistema legal y desarrollo económico" (1963-64), "Los conceptos de Estado y de propiedad privada en el Derecho positivo chileno" (1964), "La crisis del sistema legal chileno" (1964), "Principios e Instituciones jurídicas en época de Transición" (1966), "La renovación del derecho" (1968), "Hacia un nuevo derecho" (1968), "Derecho, Justicia y Violencia" (1968), “justicia de Clase?" (1970), "Progrès humain et Droit Pénal" (1970), entre otras.

${ }^{20}$ Rauff vivía en Chile desde 1958 y Novoa solicita su extradición a los tribunales chilenos en representación de la Republica Federal Alemana. Rauff no fue extraditado, pues se concluyó que en Chile no existía el delito de genocidio. Murió en Chile.

21 Villalonga, C., Revolución y ley, Op. Cit., p. 48.
} 
donde publicó numerosos trabajos), en 1964 Novoa toma una decisión que marcará su vida y en cierto sentido, a Chile. Puesto en la disyuntiva de, por un lado acercarse al candidato Eduardo Frei, abanderado del partido democratacristiano y de los sectores conservadores, que impulsaba el programa de la revolución "en libertad", o, por otro, acompañar al candidato del FRAP, Salvador Allende, apoyado por la izquierda, Novoa se decide a dar su apoyo al candidato izquierdista.

En una carta a Salvador Allende, fechada el 30 de Junio de 1964, Novoa señala que se encuentra "ante el dilema de tener que optar por una de las dos candidaturas presidenciales que ofrecen un cambio fundamental del repudiable sistema económico, político y social existente: la suya o la del señor Frei." 22 Dice Novoa, desde su posición de jurista, que es absolutamente necesario, para concretar la transformación social que debía remediar las injusticias de la época, emprender una tarea de profundas alteraciones al sistema jurídico imperante. Pone como ejemplo la necesidad de revisar el concepto de derecho de propiedad y de limitar el concepto de derecho adquirido, advirtiendo que mientras ello no se realice ambos conceptos serán obstáculos insalvables de todo cambio, y refugio seguro de los privilegiados ${ }^{23}$. Ésa es una inquietud que Novoa tratará en más de una oportunidad en su obra. Específicamente, le señala a Allende en la citada carta que: "en las actuales condiciones históricas chilenas, es usted, el que de ser elegido, tiene mejores posibilidades en este sentido" 24 .

La situación de aquel tiempo en el país era inaguantable y aquello repugnaba a la conciencia de cristiano del jurista. Podemos decir que desde aquel momento Novoa toma decidido partido por una opción política, y es en aquella situación de colaboración con el proyecto político de la izquierda chilena que ocupará importantes cargos y obligaciones $^{25}$. En 1973 es sido designado embajador en misión especial de los asuntos jurídicos chilenos en Europa, con sede en Paris, donde coordinaba la defensa del Estado de Chile ante los juicios promovidos por Braden Cooper Co. en razón de la nacionalización del cobre. Es ahí donde lo sorprende el golpe de Estado.

El militar designado como rector de la Universidad de Chile procede a través de decreto a expulsarlo de su cátedra, privándole de su trabajo, títulos y cargos, a los cuales había accedido por su mérito y gran capacidad de trabajo. En el exilio, que si bien fue,

\footnotetext{
22 Novoa Monreal, Eduardo, "Carta al candidato presidencial Dr. Salvador Allende"; Novoa Monreal, Eduardo, Obras escogidas. Una crítica al derecho tradicional, Centro de Estudios Políticos Latinoamericanos Simón Bolívar, Santiago, 1993, p. 409.

${ }^{23}$ Novoa Monreal, E., "Carta al Candidato", Op. Cit., p. 410.

${ }^{24}$ Novoa Monreal, E., "Carta al Candidato", Op. Cit., p. 411.

25 Entre muchos otros podemos señalar que integrará en representación del Fisco el directorio de la Compañía de Teléfonos de Chile y será consejero de la Comisión Chilena de Energía Nuclear. Algo poco conocido pero de gran importancia, es el hecho que Novoa fue candidato a rector de la Universidad de Chile, apoyado por la izquierda universitaria unida. Esta elección la pierde por una escasa votación ante Edgardo Boeninger (el compañero de lista de Novoa como candidato a secretario general de la Universidad era Ricardo Lagos Escobar, quien sí resulto elegido). Se desempeñó también como Presidente de la Comisión Jurídica del Cobre (órgano encargado de la defensa del los intereses del Estado de Chile tras la nacionalización de la riqueza cuprífera).
} 
según sus cercanos y según su propio testimonio, la prueba mas difícil de su vida, la dedicación exclusiva a labores académicas hizo que el nombre de Novoa creciera, alcanzando reconocimientos y puestos académicos en numerosos países y en importantes casas de estudios. La Universidad Nacional Autónoma de México, la Universidad Central de Venezuela, la Universidad de Barcelona, la Universidad de Buenos Aires se vieron beneficiadas por el infame exilio ${ }^{26}$. Sus libros alcanzaron relevancia y constituyeron lectura obligada en más de una cátedra ${ }^{27}$.

Sin embargo de ese alto reconocimiento, al volver a Chile después de 15 años de exilio, en 1987, una vez que la dictadura permitió su retorno, como a otros intelectuales que no se sumaron a los gobiernos de la Concertación, a Novoa le tocó experimentar el aislamiento. Dice Bergalli que hasta su muerte, ocurrida a fines de abril en Santiago de Chile el año 2006, no habían tenido éxito las gestiones que empezara Novoa en 1988 y que buscaban derogar el decreto que lo expulsó de la Universidad de Chile ${ }^{28}$. No tengo noticias hasta hoy, de que aquello se haya revertido, aplicando un mínimo sentido retrospectivo de justicia y moral.

Hay dos hechos en la vida de Novoa, que, más allá de los extraordinarios meritos que hemos suscintamente relatado, pueden considerarse como los acontecimientos más importantes de su vida jurídico-política. Primero, su labor como asesor jurídico adhonorem del Presidente Salvador Allende y en esta calidad, diseñador de los "resquicios legales" y protagonista decisivo de la vía chilena al socialismo. En segundo lugar, dentro del mismo contexto, pero en un acontecimiento distinto y también de primera importancia, Novoa tuvo un rol protagónico en la nacionalización del cobre. El proyecto de reforma constitucional en donde ésta se concretó fue concebido principalmente por él.

\footnotetext{
${ }^{26}$ Será Investigador del Instituto de Investigaciones Jurídicas de la UNAM, México (1974-1977), Profesor en la Universidad Central de Venezuela, donde impartirá clases en el Doctorado (1977-1982), Profesor en la Universidad de Barcelona (1982), Profesor de Derecho Penal en la Universidad de Buenos Aires (1984-1985). En la República Argentina ocupará importantes cargos científicos, como los de Investigador de la Comisión Nacional de Investigaciones Científicas y Tecnológicas, miembro de la comisión informática del Ministerio de Educación y Cultura de la Republica Argentina, Miembro de la comisión evaluadora de profesores de Derecho Penal de la Facultad de Derecho de la Universidad de Buenos Aires, entre otros.

${ }^{27}$ En Chile aún hoy los jóvenes penalistas consideran su "Curso de Derecho Penal Chileno" (1960, Tomo I, 1966, Tomo II) como la mejor obra escrita en Chile de la materia. Otras obras de gran nivel son por ejemplo, "Elementos del Delito" (1952), "¿ Qué queda del derecho natural? (reflexiones de un jurista cristiano)" (1967), obra que le permitió acceder a la cátedra de Teoría General del Derecho en la Universidad de Chile, "El Transplante de corazón" (1969), "La Batalla por el cobre (nacionalización chilena del cobre)" (1972). Además de sus trabajos en materia penal son ampliamente conocidos y estudiados en el extranjero libros suyos tales como "Nacionalización y recuperación de recursos naturales ante la ley internacional" (1974), "El derecho como obstáculo al cambio social" (1975), "Defensa de las nacionalizaciones ante los tribunales extranjeros" (1976), "Evolución del derecho penal en el presente siglo" (1978), "Universidad Latinoamericana y problema social” (1978), “¿Vía Legal al Socialismo?” (1978), "La Nacionalización Venezolana del Petróleo" (1979), "Elementos para una crítica y desmitificación del derecho" (1985), "Instrumentos Jurídicos para una política económica de Avanzada" (1987), entre otras obras de este autor extraordinariamente prolífico y de amplios conocimientos en distintos campos del derecho.

28 Bergalli, R, "Una Etica", Op. Cit., p. 7.
} 
Estos dos acontecimientos nos permitirán acercarnos al pensamiento jurídico social de Novoa, que va más allá de la técnica de un penalista. El conocimiento de su pensamiento también será importantísimo para entender los acontecimientos aludidos, esto es la nacionalización y sobre todo los resquicios legales como estrategia política, y en definitiva, lograr desde el punto de vista del derecho, informarnos más sobre hechos políticos de alta relevancia en la historia de Chile.

La vía legal al socialismo como estrategia política requería, obviamente, de técnicos en derecho, cuyos conocimientos permitieran, dentro de la perseguida legalidad, los avances hacia los objetivos políticos establecidos. El buen manejo del lenguaje jurídico, así como la técnica y el conocimiento del derecho, eran fundamentales.

Dice Novoa que la nacionalización de las cupríferas de la gran minería del cobre se basó en sólidos principios jurídicos provenientes del derecho internacional. Su argumentación se apoya en la Resolución no 1803 (XVII) de la Asamblea General de las Naciones Unidas, de sesión celebrada el 14 de diciembre de 1962, sobre Soberanía Permanente de los recursos naturales ${ }^{29}$. En aquellos años sólo se conocía en Chile la "expropiación”, institución tradicional en el derecho, de efectos mucho mas tímidos que la nacionalización. La expropiación siempre se entendió como de alcances limitados, sobre bienes determinados, y ocurría previa indemnización, ya que significaba privar de su dominio sobre un bien a un particular para satisfacer una necesidad puntual y específica del Estado.

En cambio la nacionalización, según la resolución señalada, es una vía para la recuperación, por el Estado, del derecho permanente sobre los recursos y riquezas naturales. Es decir, esta institución jurídica traduce una visión de Estado muy distinta al anterior. El derecho a nacionalizar expresa un Estado representante de una comunidad, soberano y activo, que se pone al servicio de la comunidad y no del interés de algún particular. Es un Estado que mediante la recuperación lo que hace es reparar injusticias históricas. Conforme al ritmo de los tiempos, en esos años los juristas de vanguardia estudian y aprenden en Chile a partir de los antecedentes de las experiencias de países y de ordenamientos jurídicos avanzados, como Francia, que nacionalizó los bancos, la producción de electricidad e incluso la industria automotora Renault.

Al contrario de lo que buscaban otros juristas, la nacionalización del cobre en Chile no se hace por ley, sino por una vía mayor, la reforma constitucional, dejando atrás la idea de una nacionalización entendida como expropiación, que se basa en la idea de protección a los derechos de propiedad adquiridos y en su indemnización. Atendido lo que se discute y los riesgos de rechazo que se corren, la vía de máxima legitimidad es la reforma constitucional. Dice Novoa: "esa reforma (constitucional) y la consiguiente nacionalización constituyen, por ello, una decisión soberana del pueblo de Chile,

\footnotetext{
${ }^{29}$ Novoa Monreal, Eduardo, "La nacionalización del cobre: aspectos jurídicos", Revista Mensaje, Santiago, no
} 204, 1971, p. 513. 
adoptada de forma libre y regular, ajustada a pautas jurídicas que el país se ha dado como nación independiente" 30 .

Chile, entonces, reviste de una legalidad intachable un acto político por excelencia. Para esta decisión Chile se apoya en principios, prácticas y resoluciones provenientes del derecho internacional, y más importante, en los órganos que representan la democracia chilena. Se realizan, a través de la más pura legalidad, acciones que son habitualmente repudiables para los sectores más conservadores. Los derechos adquiridos de los particulares ceden (en este caso, los derechos de grandes trasnacionales) frente a la soberanía del Estado.

Esta centralidad de la "juricidad”, como señala Novoa ${ }^{31}$, característica con que el gobierno de Chile quiso revestir todo el proceso de nacionalización, permite entender mejor el proceso político vivido durante la Unidad Popular. Porque llevando al extremo la juricidad y esta forma de maniobrar políticamente a través del derecho para realizar cambios políticos profundos, que parecen romper "principios jurídicos" consagrados y reconocidos, es como surgieron los resquicios legales.

Es importante profundizar en las inspiraciones de Novoa. Su praxis jurídica, que se confunde finalmente con la política de la Unidad Popular, no puede entenderse sino teniendo en consideración la postura de adhesión de Novoa a un radical positivismo de raíz Kelseniana. Al contrario de lo que se ha dicho, me parece inadecuado catalogar a Novoa como un jurista a caballo entre Marx y Kelsen ${ }^{32}$, pues, si en algunos escritos parece tomar algunas ideas de Marx, en la práctica de los resquicios sigue precisamente la principal advertencia que el vienés hacía a los interesados en la depuración del derecho: no confundirlo con la política.

Si estudiamos las argumentaciones y los razonamientos que se usaron para justificar los resquicios legales, caeremos en cuenta que Novoa se inclina por un positivismo jurídico bastante radical. Contra lo que se pudiese imaginar de un cristiano que, como hemos visto, es cercano al socialismo y adhiere al programa político de la Unidad Popular por razones profundamente éticas, Novoa, en cuanto jurista, pretende que se vea al derecho como "vacío de contenido, instrumental y desideologizado"33.

En el pináculo de su carrera, y ya dejado atrás el iusnaturalismo, Novoa fustiga a quienes pretenden que el derecho sólo debe entenderse por tal y, por ello, tiene que ser capaz de obligar a los individuos cuando coincida con normas básicas del derecho natural. Esto, según Novoa, es entender una disciplina teórica (el derecho) como si estuviera animada por "conceptos fantasmagóricos" y llena de ideas "inaprensibles" 34. Esta identificación del derecho con una supuesta idea de justicia natural (sea que

\footnotetext{
30 Novoa Monreal, E., “La nacionalización”, Op. Cit p. 513.

31 Novoa Monreal, E., "La nacionalización”, Op. Cit p. 515.

32 Villalonga, C., Revolución y Ley, Op. Cit., p.111.

33 Novoa Monreal, Eduardo, Elementos para una crítica y desmitificación del derecho, Ediar, Buenos Aires, 1985 , p. 159.

34 Novoa Monreal, E., Elementos para una crítica, Op. Cit. p. 160.
} 
provenga de Dios o de la razón) es, según Novoa, irreal, pues lo que en realidad consigna el derecho son las ideas y conceptos de los interesados en seguir ejerciendo el poder contra las grandes mayorías humanas. Son finalmente estos intereses de unos pocos los que pasan a tener estatus de principios o conceptos demostrados por la "ciencia del derecho". De este modo, determinar lo que es bueno o justo es una función que queda radicada en un grupo determinado, los juristas, como un conocimiento hermético, provisto de un vocabulario especial, técnico e intimidante, que existe a través de un sistema cerrado con pretensiones de perfección y universalidad.

Esas ideas "fantasmagóricas" son las que, según Novoa, permiten a las fuerzas de la reacción emplear al derecho como "fetiche", intocable y protegido por sacerdotes y pontífices, que emplean la execración contra cualquier mente crítica o renovadora. Las concepciones iusnaturalistas, apriorísticas, parten de la base de que la última verdad del derecho y de la moral, que se mezclan promiscuamente, se desprende de ideas intemporales y absolutas, y por ello están desprovistas de ideología política o de interés de clase; por ende, nada podría empañar tan noble verdad científica imparcial e ideal. Pero es contra tal concepción del derecho que Novoa argumenta, sosteniéndose en un Kelsen para muchos desconocido.

La Teoría Pura del Derecho elaborada por el sabio vienés de origen judío, en perspectiva kantiana, pretende mantener a la ciencia jurídica separada de la política y orientarla hacia la objetividad y precisión tanto como se pueda, indagando lo que el derecho es y cómo se forma en vez de considerarlo "como debería ser". Si bien mayoritariamente se entendía que el derecho no era tal si no respondía a la idea moral de justicia (o a una idea de ésta, más bien), tal postura queda herida de muerte después de sus planteamientos. En su marco, los juristas debieran interesarse en las normas, y esto significa el aspecto formal de éstas, es decir, analizar una exigencia de conducta y también inventar y aplicar la sanción, si no se cumple con esta exigencia, pero sin considerar su contenido, o sea sin preguntarse porqué y para qué ésta se prescribe. Es decir, la norma se independiza del fin social y práctico que la inspiró, separándose de la política y de cualquier ideología. Eso es el derecho, según Kelsen y según Novoa.

El derecho suele ser despreciado por los teóricos sociales. En el tiempo que nos ocupa fue despreciado por el marxismo, pues éste no "vio" la distinción entre forma y contenido de las normas, condenando al derecho como integrante de la superestructura del modo de producción en que la clase dominante somete a la dominada ${ }^{35}$.

Como señalé anteriormente, son los propios abogados los que comienzan a contextualizar las relaciones entre derecho y sociedad. El derecho sería entonces un elemento ideologizante y poco más. Pues bien, Novoa acepta que sí lo es. Pero Novoa es abogado, no un filósofo, y por ello cree que el derecho es también una de las disciplinas más prácticas de las que conoce el ser humano. Si se descubre lo específicamente jurídico es posible obtener, como en cualquier disciplina, el desarrollo

35 Novoa Monreal, E., Elementos para una crítica, Op. Cit. p. 168. 
del derecho, como lo vemos con la utilización del concepto de nacionalización, y así utilizarlo como mecanismo social. Hablar de un derecho puramente formal, a pesar de los iusnaturalistas mejor intencionados, implica que el derecho queda al servicio de cualquier ideología política y es ésta forma de entenderlo la única manera de otorgarle al derecho el estatus de neutro ideológicamente.

Novoa es un práctico, repito, un técnico que pone su saber al servicio de sus propias concepciones morales y del proyecto político al que adhiere. El uso técnico de las normas, apoyado en un elevado conocimiento de las más avanzadas teorías jurídicas llevadas a un límite, es lo que puede explicar la confianza en el uso de los resquicios legales como opción para concretar el programa económico de la Unidad Popular. La posición jurídica de Novoa, a grandes rasgos, es compartida por el gobierno de Salvador Allende y debe entenderse como la explicación oficial para los resquicios legales que éste puso en marcha. Así escribe Joán Garcés cuando acusa que, en otra vereda, tanto los marxistas como sus acusadores y denunciantes compartían un mismo modo de entender el derecho ${ }^{36}$.

\section{El contexto político y la búsqueda de la legalidad}

Es necesario, previamente a una comprensión informada de los resquicios legales, establecer un panorama de las circunstancias que vivía el país en la época de su aplicación, así como del periodo inmediatamente anterior.

El 17 de diciembre de 1969 los partidos políticos de izquierda (socialista, comunista, radical y socialdemócrata, además del Mapu y el Movimiento de acción popular independiente), aprobaron en Santiago un programa básico de gobierno que debía servir como plataforma para la elección presidencial próxima. Salvador Allende Gossens, militante socialista, una vez ungido candidato presidencial del conglomerado, hizo suyo el programa.

Por cierto, no es éste el lugar para analizar el diagnóstico complejo del país que se observa en el programa y los planteamientos para su superación, pero en términos generales se advierte un estancamiento económico y social, pobreza generalizada y postergaciones de variada índole sufridas por obreros, campesinos y demás capas explotadas. Para terminar con el capital monopolista nacional y con el latifundio se debía subordinar completamente el primero a los intereses nacionales, y eliminar completamente el segundo. También (y es uno de los objetivos fundamentales que no se logró con la utilización de los resquicios) debía procurarse un crecimiento económico rápido a través del desarrollo máximo de las fuerzas productivas y el óptimo aprovechamiento de los recursos humanos, naturales, financieros y técnicos disponibles.

La base para obtener estos resultados y lograr una planificación económica de carácter ejecutivo sería la adquisición, por el Estado, de los medios de producción

\footnotetext{
${ }^{36}$ Garcés, Joan, El Estado y los Problemas Tácticos en el gobierno de Allende, Fondo de Cultura Económica, Madrid,
} 1974, p. 232. 
fundamentales. El instrumento creado para ello fue la llamada Área de Propiedad Social, que debía formarse reuniendo las empresas que en ese momento poseía el Estado con las que serían expropiadas ${ }^{37}$. Como primera medida se nacionalizarían las riquezas básicas en manos del capital extranjero y de los monopolios internos como la gran minería del cobre, hierro, salitre y otras, así como el sistema financiero (bancos y seguros), monopolios industriales, de distribución, entre otros ${ }^{38}$.

Algo fundamental del discurso de la Unidad Popular era que tal proyecto político consistía en que el logro de un socialismo real (alejado del reformismo democratacristiano de Frei) se podía lograr a través de una vía institucional, acorde con la reiterada y cuestionable tradición, conciencia o mentalidad legalista nuestro país. Tal forma de entender el logro de una sociedad socialista, se decía, estuvo siempre presente en los clásicos marxistas, quienes señalaban que cada pueblo debía, según sus características propias, optar por un camino particular, y quienes, además, nunca sobrestimaron la vía armada.

Elegido Allende como presidente - como sabemos, debido a un margen escaso de votos frente al empresario Jorge Alessandri Rodríguez- es ratificado por el Congreso debiendo superar primero un conjunto de grandes problemas (procedimiento nunca antes visto en la historia chilena), que anunciaban al gobierno electo y a la población que el mandato de la Unidad Popular había nacido con dificultades y trabas. Podemos mencionar entre los más importantes, por ejemplo, movimientos especulativos de activos financieros; un discurso hecho por el ex ministro y hoy senador Andrés Zaldívar que pretendía crear pánico ente los empresarios; $y$, ciertamente, una serie de hechos que Novoa llamó "las andanzas de la CIA"39 4041.

Punto aparte, pues es un tema de cuya complejidad ha sido poco explorada hasta este momento, es el llamado Estatuto de Garantías Constitucionales. El 16 de septiembre el Consejo Nacional de la Democracia Cristiana aprobó por unanimidad un documento elaborado por una comisión especial encabezada por Benjamín Prado, en el que se daba vida a "un estatuto de garantías" destinado entre otras cosas a asegurar el respeto a la autonomía de la universidad, de las fuerzas armadas, la libertad de educación en las escuelas, libertad de expresión, libre funcionamiento de los partidos,

\footnotetext{
${ }^{37}$ Novoa Monreal, E., Los Resquicios, Op. Cit., p. 49.

${ }^{38}$ Se propone la construcción de una "nueva economía" que supone a su vez la constitución de tres áreas económicas, una de las cuales, la dominante, quedará en manos del Estado. Otra permitirá la subsistencia de propiedad privada sobre los medios de producción y una tercera permitirá que el Estado tenga cabida en las actividades económicas de los particulares: propiedad social, propiedad privada y propiedad mixta.

${ }^{39}$ Novoa Monreal, E., Los resquicios, Op. Cit., p. 19.

40 A este respecto el resultado más siniestro es sin duda el secuestro y asesinato del comandante en jefe del ejército René Schneider por un comando de derecha en un desesperado afán desestabilizador. Era la pista (track) II, la cual más adelante saldría a la luz, como parte de los planes de la inteligencia norteamericana para impedir a Allende la toma de su cargo.

${ }^{41}$ Es interesante hacer notar que la misma judicatura que se opuso tan tenazmente, por ir contra la juridicidad a los resquicios legales y al gobierno de Allende, estimó que la pena que correspondía a los culpables del primer asesinato terrorista en la historia de Chile era de 5 años de pena de extrañamiento.
} 
en fin, a que se asegurara, dicen, en Chile, una sociedad pluralista en lo político, social y cultural $^{42}$. El 25 de Septiembre la Democracia Cristiana dio a conocer un documento llamado "Posición del Partido Demócrata Cristiano ante el congreso pleno", donde afirma que si Allende entregaba las necesarias garantías a los parlamentarios democratacristianos, podía contar con sus votos para la ratificación en el congreso.

Tal petición, y la formulación misma del Estatuto movió a escándalo: ambos gestos fueron considerado como una afrenta gratuita por los sectores de la izquierda. ¿Por qué exigir garantías especiales? En el mecanismo constitucional de la vigente Constitución de 1925 se establecía para la elección presidencial un procedimiento eleccionario, que, a falta de triunfo decisivo de alguno de los candidatos, culminaba con la designación de presidente electo por el Congreso Pleno. Por cierto había una facultad del Congreso para elegir y se podía haber optado por proclamar a Jorge Alessandri; pero eso, se dice, contradiría las prácticas políticas de la historia de Chile. La verdad es que jamás se entendió, antes de Allende, que haber obtenido un porcentaje menor al $50 \%$ en las elecciones presidenciales rebajaba de status al candidato designado por el Congreso Pleno, o que pudiese poner en duda su legitimidad para el cargo. Sin ir más lejos, dice Novoa, nadie siquiera pensó que Jorge Alessandri fuera un presidente "de segunda clase" por no haber obtenido ni un tercio de la votación popular en 1958 (de hecho obtuvo el 31, 5\%) ni se procedió con estridencia a exigirle seguridades solemnes para asegurar al país que no fuese a hacer un gobierno dirigido a satisfacer los interes es de los empresarios, destruyendo los derechos obtenidos por los trabajadores ${ }^{43}$.

No obstante, Allende finalmente aceptó las exigencias de la Democracia Cristiana. Su decisión obedecía a un cálculo, pues con ella contaba con 75 votos más en el Congreso Pleno, lo cual contribuía a reforzar aún más su limpísima victoria. El 8 de octubre se presento a la cámara de diputados un proyecto de reforma constitucional que satisfacía el requerimiento democratacristiano. Fue promulgado finalmente el 9 de enero.

Es importante tener presente que el Estatuto de Garantías Constitucionales reviste interés desde tres puntos de vista. En esta exposición sigo parcialmente a Novoa:

Primero. Las garantías constitucionales son todas de índole política, sin que en ellas se encuentre ninguna referencia a lo económico. Es decir, sabiendo los democratacristianos que gran parte del programa de la Unidad Popular se basaba en cambios económicos, no incorporó disposiciones que diesen protección a los derechos económicos adquiridos, concretamente, en el sentido de impedir la aplicación de legislación vigente, como los resquicios legales, que posteriormente ellos no se cansaron de atacar. ¿Qué ocurrió?, se pregunta Eduardo Novoa. No olvidemos que su partido contaba con un equipo de connotados juristas y profesores de derecho capaces de abordar anticipadamente este tema ${ }^{44}$.

\footnotetext{
42 González, Francisco Javier, Partido Democratacristiano. La lucha por definirse, Instituto de Estudios Generales, Valparaíso, 1989, p. 198 y ss.

43 Novoa Monreal, E., Los resquicios, Op. Cit., p. 31.

44 Novoa Monreal, E, Los resquicios, Op. Cit., p. 39.
} 
Segundo. Como ya señalamos, ilustra claramente acerca del ambiente hostil al que deberá enfrentarse el gobierno, es decir, trasluce lo que será una realidad, el bloqueo que el Parlamento y que los órganos legislativos harán contra el programa de gobierno.

Tercero. Posiblemente uno de los grandes errores que el gobierno y su equipo jurídico pudieron cometer fue anatemizar el Estatuto, sin valorar en adecuada medida el contenido constitucional altamente progresista que éste contenía, sobre todo en lo relativo al derecho al trabajo, atención médica, participación cívica, política y cultural. Como pretendemos, son disposiciones constitucionales que, aplicadas correctamente pudieron contribuir a un verdadero avance político social por las vías del derecho. Posiblemente no se advirtió que importantes partes del texto son casi reproducciones textuales de la Constitución italiana de 1947 (artículo 3º), que se situó a la vanguardia de la corriente política que buscaba consagrar los derechos constitucionales de modo que fuesen derechos efectivos para la gran mayoría de la población (el gran inspirador de esto fue el histórico dirigente comunista Palmiro Togliatti), y que posteriormente fueron seguidas por las constituciones de España y Portugal. Es dable pensar que, teniendo lo anterior en cuenta, se podría haber avanzado hacia una verdadera crítica al derecho tradicional chileno, apoyada por razonamientos basados en el texto constitucional y en un uso alternativo de éste. El resultado habría estado a favor de las masas explotadas (fenómenos parecidos a los producidos en Italia y España, y también en Brasil), y posiblemente habría sido muy superior al fenómeno chileno de los discutidos resquicios legales. Visto éste como un vejamen al orden, y no como una posibilidad positiva de cambio, no se le tomó en cuenta como alternativa para realizar un avance notorio en el ordenamiento socio-jurídico de Chile. El profesor Novoa, hombre íntegro e ideas claras, señala: "ahora, al reparar en ello, confieso mi culpa" 45.

\section{Los resquicios legales como herramienta para formar el Área de Propiedad Social}

Como consecuencia de todo lo anterior, el presidente Allende no podía esperar hacer efectivo su programa de gobierno sino con leyes que ya estaban vigentes al momento de su elección. El Congreso no proporcionaría ni proporcionó espacio para generar nueva legislación que permitiese avanzar en el sentido que deseaba Allende. La única excepción, ocurrida por motivos circunstanciales, fue la nacionalización del cobre, que en la práctica se tradujo como gesto transversal de apoyo al gobierno de Allende. Sin embargo, aunque muchos señalan que la aprobación del Congreso a esa iniciativa fue una inequívoca señal de respaldo al gobierno socialista, en realidad fue sólo acto de patriotismo unánime frente a intereses internacionales ${ }^{46}$.

\footnotetext{
45 Novoa Monreal, E., Los resquicios, Op. Cit., p. 39.

${ }^{46} \mathrm{El}$ apoyo que el Congreso Nacional dio a la nacionalización del cobre, de cuya ley fue el mismo profesor Novoa principal artífice como vimos anteriormente, es una cuestión excepcional, pero además ha sido un tanto mitificada. La mayoría de votos favor que se logró en el Congreso, no sólo fue circunstancial, sino que implicó condiciones bastante más negativas de lo que se cree. Por ejemplo, no sólo se adquirieron los activos: el Estado debió hacerse cargo también de las deudas de las mineras.
} 
El dilema de Allende era el siguiente: o renunciaba al programa anunciado en su campaña o encontraba "una solución imaginativa". En concreto, la tarea que le encomendó Allende a Eduardo Novoa (como asesor jurídico ad-honorem) fue encontrar, dentro de la legislación vigente, apoyo para realizar los primeros cambios que se pretendía, fundamentalmente en el ámbito económico. Es decir, lo que urgía era empezar a formar el área de propiedad social.

La idea siempre fue no violar el ordenamiento constitucional. Pero la creación del área social era fundamental para la vía chilena al socialismo, pues ésta dependía de un proceso social amplio y acelerado que atrajera cada vez más a sectores del país a las filas de la Unidad Popular, hasta lograr una mayoría incontrarrestable que fuera apta para superar constitucionalmente cualquier obstáculo, jurídico o de otra índole ${ }^{47}$. El mismo Eduardo Novoa había denunciado lo que llamó "crisis del sistema legal chileno"48, que se manifestaba en falta de organicidad, desorden, falta de método y, algo muy importante para el tema que nos ocupa, el antagonismo de principios orientadores, existiendo contradicciones entre las ideas y las ideologías que inspiraban muchas leyes ${ }^{49}$. Dentro de esa maraña se esperaba encontrar elementos que pudiesen servir a los fines del gobierno: allí había de todo, y no por eso lo que resultara sería menos ley o menos derecho que el Código Civil de Andrés Bello.

Efectivamente se busco y se encontró. Los cinco órdenes de preceptos fueron los siguientes:

1) El Decreto Ley 520 (dictado en 1932), que es el que mejor se allanaba a la formación de la propiedad social y al que nos referiremos un poco más detalladamente (permitía la expropiación en ciertos casos de predios agrícolas y empresas declaradas de utilidad pública).

2) Disposiciones dispersas que otorgan atribuciones discrecionales a diversas autoridades y organismos; por ejemplo, la ley orgánica de la CORFO (que permitió entre otras cosas adquirir acciones de compañías tales como Compañía de Aceros del Pacifico o Sudamericana de Vapores).

3) También se aplicó la legislación tradicional basada en principios de antigua data, como el máximo informador del derecho privado, la autonomía de la voluntad, lo que se plasmó en la compra de la propiedad de empresas (mediante la adquisición de acciones). Es decidor que a través de este mecanismo se llegase a un altísimo nivel de nacionalización de la banca.

4) Normas como el Decreto con Fuerza de Ley $n^{\circ} 274$, que crea la Empresa de Comercio Agrícola, que si bien tenía en principio la misión de fijar el precio del trigo, llegó a tener varias atribuciones, como abastecer zonas del país que estaban en

\footnotetext{
47 Corvalán, Luis, El Gobierno de Salvador Allende, LOM, Santiago, 2003, p. 55 y ss.

48 Novoa Monreal, Eduardo, "La crisis del sistema legal chileno”, Revista Mensaje, Santiago, no 134, 1964, p. 559-556.

49 Santos, Boaventura, Crítica de la razón indolente, Descleé Brouwer, Bilbao, 2003, p.156 y ss.
} 
desabastecimiento, exportar trigo y otros productos agropecuarios y realizar operaciones de comercio.

5) Otras medidas que se usaron, pero ante las cuáles Novoa se expresa de manera poco clara (por momentos parece rechazarlas ${ }^{50}$, y en otro lugar parece que le son simpáticas ${ }^{51}$ ), son las que permitían nombrar interventores en las industrias cuando surgían conflictos laborales; su propósito era evitar a la colectividad el daño generado por la paralización de faenas, disponiendo su reanudación. Novoa señala que se pretendió darles carácter de duraderas, siendo que en realidad eran medidas esencialmente transitorias ${ }^{52}$.

\section{El problema de la conceptualización y vigencia de los resquicios y en particular del Decreto Ley 520}

Desde una perspectiva conservadora, Enrique Brahm señala que "los resquicios son el recurso a normas legales existentes que usadas adecuadamente y en forma masiva debían transformarse en lo que hemos llamado medios indirectos para alcanzar la socialización" 53 . Desde una perspectiva cercana a la anterior, que también se opone a la lógica de su utilización, Cristian Villalonga reconoce la validez de los resquicios legales, pero va más allá, señalando que "a pesar de una opinión generalizada contraria existió (antes del gobierno de Allende) una permanente aplicación del Decreto Ley 520”54.

En el idioma castellano un resquicio es en general una abertura (también puede ser una oportunidad) pequeña. Por esto Novoa señala que comienza a darle el verdadero sentido a la expresión "resquicio" 55 como lo que fueron, esto es, medidas utilizadas en forma hábil e imaginativa, indiscutibles en su validez, aunque tal vez olvidadas, pero que eran plenamente apropiadas para la finalidad perseguida por el Presidente Allende ${ }^{56}$.

Pareciera que todos están de acuerdo hoy en la validez de las normas referidas. Pese a ello, desde una literatura reticente y enfática, que busca imponer un discurso oficial acerca de la legalidad del gobierno del presidente Allende, se sigue señalando que la implementación de los resquicios legales fue una "maniobra torcida". ¿Cómo podemos entender esto?

Veamos el gran hito de la aplicación de los resquicios, la expropiación de la fábrica de paños Bellavista Tome S. A. (ocurrida el 2 de diciembre de 1970), que estaba

\footnotetext{
50 Novoa Monreal, E., Los resquicios legales, Op. Cit., p. 56.

51 Novoa Monreal, Eduardo, "Vías legales para avanzar al socialismo", Revista de Derecho Económico, Santiago, no 33 y 34, 1971, p. 25.

${ }^{52}$ Las disposiciones se encuentran en el artículo 626 del código del trabajo de 1931, ley 12.927 sobre seguridad interior del Estado (1958), en el mismo Decreto Ley 520, etc.

53 Brahm García, E., "La perversión”, Op. Cit., p. 336.

54 Villalonga, C., Revolución y ley, Op. Cit., p. 124.

55 Novoa dice no saber quién empezó con esto de los resquicios legales y cree que fue El Mercurio. En todo caso, le hizo gracia y empezó a llamarlos así también. Novoa Monreal, E., Los resquicios legales, Op. Cit., p. 71

56 Novoa Monreal, E., Los resquicios legales, Op. Cit., p. 7.
} 
paralizada desde septiembre de 1970. El articulo 4 del Decreto Ley 520 señalaba cuáles eran las empresas declaradas de utilidad pública ${ }^{57}$, entre las que debía considerarse esta empresa. Según el articulo 5 se ordenaba la expropiación de todo establecimiento industrial que permaneciera en receso. El 2 de diciembre de 1970 se publica en el Diario Oficial el decreto expropiatorio ( $n^{\circ} 1180$ de Ministerio de Economía). Para ello debió superar el filtro del Consejo de Defensa del Estado, que estaba integrado por prestigiosos abogados, todos contrarios al gobierno (excepto el propio Novoa, que en ese momento era su Presidente), quiénes reconocieron la regularidad de la expropiación. A continuación, la Contraloría tomó razón del decreto, considerándolo legal. Es decir, se cumplieron los requisitos vigentes de legalidad.

Al principio, se dice, los abogados más importantes del foro, es decir, los que representaban a las grandes empresas, manifestaron su sorpresa, pues no conocían las normas a las que obedecía tal acto administrativo. El diario santiaguino El Mercurio, en una faceta más de su abierta campaña de desprestigio del gobierno de Allende, declaró que los preceptos evocados -a los que calificó de "resquicios"- eran contrarios a la Constitución y agregó incluso que eran "inexistentes", acusándolos de ser una interpretación arbitraria de la ley. Poco a poco, sin embargo, esos mismos abogados comprendieron la falta de sustento de sus argumentos y comenzaron entonces a calificar a los resquicios legales aplicados por el gobierno de Allende como "dudosos" y provenientes de estudios jurídicos "esforzados”. Alejandro Silva Bascuñán, importante constitucionalista y presidente del Colegio de Abogados, en un estudio publicado el 14 de agosto en el periódico ya citado, El Mercurio de Santiago, los califica como textos de "contradictoria interpretación y procedencia espuria" 58 . Es decir, a muy poco andar se abandona el debate jurídico tradicional para entablar el duelo en términos orientados políticamente, tratando en lo posible de quitarle al gobierno la tan preciada legitimidad y su carácter de gobierno legalista.

Pero, ¿existían razones jurídicas para desvirtuarlos?

La paradójicamente llamada Confederación Democrática (CORE) señaló que tales prácticas eran una "desviación del poder" ${ }^{9}$, lo cual no agrega nada a la discusión jurídica, aunque existieron voces, algo más serias, que señalaban que estas prácticas violaban la garantía constitucional de propiedad. Probablemente, quienes así razonaban se orientaban a partir del criterio de propiedad tradicional, muy arraigado en los juristas de la época, de origen romanista, y que provenía directamente del artículo 582 del Código Civil de 1855. Ese criterio permitía el goce y disposición "arbitraria” de la cosa sobre la cual el derecho recaía, siempre que no se actuara contra la ley y contra el

57 Artículo 4: "Para el solo efecto de atender a las necesidades imperiosas de la subsistencia del pueblo, se declaran de utilidad pública los predios agrícolas, las empresas industriales y de comercio y los establecimientos dedicados a la producción y distribución de artículos de primera necesidad; y se autoriza al Presidente de la República para expropiarlos en los casos taxativamente enumerados en los artículos $5^{\circ}$ y $6^{\circ}$ y de conformidad a las normas de procedimiento que señala la presente ley."

58 Novoa Monreal, E., Los resquicios legales, Op. Cit, p. 74.

59 Villalonga, C., Revolución y ley, Op. Cit., p. 141. 
derecho ajeno. No obstante, el concepto de Función Social de la propiedad, y con esto, una nueva forma de entenderla, estuvo ya presente en las discusiones de la Constitución de 1925 y se explicita con la Reforma Constitucional de 1967, fundamental para la reforma agraria en el gobierno Eduardo Frei Montalva (1964-1970). En el artículo 10 de la Carta Fundamental se dice que

"la función social de la propiedad comprende cuanto exijan los intereses generales del Estado, la utilidad y salubridad públicas, el mejor aprovechamiento de las fuentes y energías productivas en el servicio de la colectividad y la elevación de las condiciones de vida del común de los habitantes." ${ }^{\circ 0}$

Sin embargo, tal cual señala Cordero Quinzacara ${ }^{61}$, tanto los tribunales como los intérpretes siguieron viendo el derecho de propiedad sólo en un sentido unidimensional, enraizado en la concepción clásica, la que estaba además consagrada por el liberalismo codificador. Así, se atendía sólo a la faz subjetiva de derecho subjetivo, dejando de lado la faz objetiva del derecho de propiedad, que permite entenderlo como una institución. Señala este autor que:

"La primera se sitúa en la esfera del titular del derecho de goce y disposición para, desde la misma, afirmar el principio de libertad dominical de uso y provecho con las solas limitaciones (externas) que el interés común le imponga. Por su parte, la segunda se coloca, por el contrario, justamente en el lugar de los intereses colectivos o comunitarios para, sin desconocer los del titular del derecho, sostener la primacía de los mismos y reducir la libertad del propietario al espacio residual resultante (conforme, en todo caso, al interés general)" ${ }^{62}$.

La primera manera de entenderlo, por cierto, sólo puede responder a la idea de un estado liberal burgués. La segunda, en cambio, responde a las necesidades de un Estado Social, condiciones a las que Chile avanzaba en el siglo XX.

Además, agreguemos, la ley de reforma constitucional de Julio de 1971 destinada a la nacionalización de la gran minería del cobre, a la que ya nos hemos referido, viene a dar al traste con la rancia idea de la protección sagrada de los "derechos adquiridos" y con la comprensión unidimensional del derecho de propiedad. Como es sabido por todos, las normas constitucionales son de mayor jerarquía que las simplemente legales. Por lo tanto, una disposición del Código Civil, que no es sino una ley (ciertamente una ley muy especial, pero ley al fin y al cabo), no podría comprenderse sino a la luz de las disposiciones constitucionales. De hecho, y aún realizando el errado ejercicio de someter normas constitucionales a la interpretación del Código Civil (el constitucionalismo moderno recuerda que no puede interpretarse una norma política como la constitucional a partir de razonamientos ideados para normas de derecho

\footnotetext{
${ }^{60}$ Ley 16.615 del 20 de Enero de 1967.

${ }^{61}$ Cordero Quinzacara, Eduardo, "La Dogmática Constitucional de la Propiedad en el Derecho Chileno", Revista de Derecho, Santiago, vol. XIX, no 1, Julio 2006, p. 132.

${ }^{62}$ Cordero Quinzacara, E., “La Dogmática Constitucional”, Op.Cit., p. 126.
} 
privado), aplicando conocidas reglas, como el elemento sistemático (donde el sentido de la legislación se busca más allá de la propia ley interpretada, analizando, como lo establece el inciso $2^{\circ}$ del articulo 22, otras leyes, particularmente si versan sobre el mismo asunto), o como las referidas a la búsqueda del espíritu general de la legislación y a la equidad natural (indicadas en el articulo 24), se debiese entender al concepto tradicional de propiedad -considerada exclusivamente como derecho subjetivo- como un resabio histórico. Entender lo contrario se puede explicar por una deficiencia en la apreciación interpretativa y dogmática de las normas, aunque también el sistema de control de constitucionalidad chileno, confiado a los tribunales ordinarios, contribuyó a la limitada interpretación y a la perpetuación de criterios a que nos hemos referido ${ }^{63}$.

En todo caso, y sin olvidar lo dicho, es la propia constitución de 1925, en el mencionado artículo 10, la que recoge la garantía al derecho subjetivo de propiedad, conciliando lo antiguo con las nuevas necesidades sociales: "nadie puede ser privado de su propiedad sino en virtud de ley general o especial que autorice la expropiación por causa de utilidad pública o interés social, calificada por el legislador". El atentado contra la propiedad, sostenido en las razones tradicionales, cedía ante el argumento de texto. La expropiación era posible en Chile de mediar una ley que lo autorizara.

Sin embargo, parece que nadie pensaba que en Chile ya existían leyes que permitían generalizar las expropiaciones que el gobierno de Allende necesitaba para conformar el Área de Propiedad Social. Es claro que el Congreso había decidido que no facilitaría la aprobación de un nuevo marco legal, que no accedería a la intención del gobierno de Allende. Y con esa determinación política, los interesados en no cambiar la situación ni el concepto tradicional de la propiedad estaban tranquilos. Pero surgió la posibilidad abierta por el bullado Decreto Ley 520. Por ello, sin contar los argumentos políticos o tinterillescos basados en la intangibilidad sagrada de la propiedad, el único argumento sostenible seriamente en contra del decreto ley 520 era su vigencia.

Durante los cien días que duró la República Socialista de 1932 se dictó una muy abundante legislación inspirada en la supuesta idea de favorecer a las clases populares. Éste, como sabemos, fue un gobierno de facto, que siguió al golpe militar de 1932 y que, al dictar su legislación, por cierto, prescindió del Congreso Nacional. Tales disposiciones emanaron del poder ejecutivo de facto, ya sea la junta de gobierno o más tarde del presidente provisional. Así, los ataques a la validez del Decreto Ley 520 se fundaron en que aquellos tenían origen "espurio". Villalonga ${ }^{64}$ señala que éstos son argumentos "jurídicos” y que los sostuvieron Silva Bascuñan y Juan Carlos Dörr. Pero decir que una ley tiene origen espurio no es un argumento jurídico, sino un sofisma. Probablemente se podría decir, y tal vez alguien lo dijo, que estas normas adolecen de

\footnotetext{
${ }^{63} \mathrm{El}$ tribunal Constitucional se introduce en el año 1970 por reforma constitucional, a través de un modelo de control previo de constitucionalidad de las leyes. Es decidor que este organismo, en lo relativo a su función de resolución de conflictos de competencia entre el parlamento y el ejecutivo, dio la razón en forma sistemática al gobierno.

${ }^{64}$ Villalonga, C., Revolución y ley, Op. Cit., p. 140.
} 
graves vicios en su generación, pues varias de ellas versaban sobre materias reservadas a la ley, que debe cumplir para ser tal el procedimiento constitucional, y en particular, la concurrencia del congreso nacional. Así, tales actos adolecerían de inexistencia jurídica ya que carecen de requisitos esenciales para ser considerados legítimamente actos administrativos, pues el ejecutivo, además de ser de facto, en todo caso estaba sobrepasando los límites constitucionales. Habría allí, en el lenguaje publicista, una nulidad de derecho público. Esto es así, ateniéndonos al artículo 4 de la Constitución de 1925 que señalaba:

\footnotetext{
"Ninguna magistratura, ninguna persona, ni reunión de personas pueden atribuirse, ni aún a pretexto de circunstancias extraordinarias, otra autoridad o derechos que los que expresamente se les hayan conferido por las leyes. Todo acto en contravención a este artículo es nulo".
}

Ahora bien, tanto Novoa como sus detractores insistieron en algo que no es real, esto es, que esta situación no era conocida y que cuando el Decreto Ley 520 se puso en aplicación significó un golpe sorpresivo de parte del gobierno. El mismo Arturo Alessandri Palma, una vez restablecida la constitucionalidad y elegido presidente del país, designó una comisión de juristas para analizar el tema del reconocimiento o no de los 669 decretos leyes dictados durante el breve periodo de la República Socialista. El informe de los juristas, en líneas gruesas, señala que dichas disposiciones son nulas $A b$ initio y no se les debe considerar como leyes ${ }^{65}$. Pero en la práctica, tanto los tribunales como el legislador constitucional no se vieron en la posibilidad de negarles valor. Estos textos fueron aplicados, algunos derogados y otros modificados por múltiples leyes. Las modificaciones introducidas legalmente al decreto ley 520 lo hacen ser una ley sin posibilidad de objeciones. De hecho, tantas fueron sus modificaciones, que en 1953 se expidió por Decreto 1.262 un texto refundido de sus disposiciones. En 1966, en virtud de la ley 16.464, parte importante de sus disposiciones fueron incorporadas al texto revisado y refundido de la legislación económica sobre costos, precios y abastecimiento de bienes y servicios de primera necesidad ${ }^{66}$. Los decretos refundidos son dictados por el Presidente de la República, refundiendo las disposiciones legales sobre una materia contenida en leyes diversas. Estos, como dice el profesor Ducci "no son una manifestación de voluntad del Presidente de la República, sino del legislador, y constituyen en todo una verdadera ley" 67.

\footnotetext{
65 Aquella comisión fue designada por el Decreto Supremo 3.479 del 25 de Agosto de 1933, que entre otros contaba con el Presidente renunciado que precedió a la República Socialista, el destacado profesor Juan Esteban Montero, y también, con profesores de la autoridad de Luis Claro Solar y el hijo de Alessandri Palma, el profesor Arturo Alessandri Rodríguez, quien fue el único miembro de la comisión que se pronunció por la validez de las normas.

${ }^{66}$ Novoa Monreal, E., "Vías Legales", Op. Cit., p. 3.

${ }^{67}$ Ducci, Carlos, Derecho Civil, Parte General, Editorial Jurídica de Chile, Santiago, 2005, p. 49.
} 
En el caso de la expropiación de la industria de paños Bellavista, el Consejo de Defensa del Estado declaró la constitucionalidad de la norma ${ }^{68}$, y señaló que se encontraba "legitimado por la doctrina, la práctica administrativa y la dictación de legislación regular posterior" 69 .

\section{La Suprema Corte y la lucha por la juricidad. Un pequeño acercamiento a los organismos jurídicos y su posición}

Debido a lo anterior, y para comprender el flaco debate en torno al tema, caben dos posibilidades: o no existen argumentos jurídicos contra los resquicios legales, o bien no se formularon.

Así, alejándose del razonamiento jurídico, Novoa dice que para detener su aplicación, la Corte Suprema se atribuyó facultades que la ley no le daba y se inmiscuyó en áreas constitucionalmente vedadas, sumándose, en los hechos, a la presión sostenida con argumentos ajenos al derecho.

El ejemplo de esto es la mítica requisición de la industria santiaguina Yarur (ocurrida el 28 de Abril 1971), motivada por el desabastecimiento producido por la huelga de trabajadores ${ }^{70}$. Es decir, ésta tiene su motivación en la satisfacción de necesidades sociales, por ello es una requisición por regulación económica, no solamente una de las denominadas requisiciones por sanción administrativa ${ }^{71}$. La cuestión tiene que ver con el procedimiento impugnatorio de la requisición. Además de existir una reconsideración ante el director de DIRINCO, existía según la ley 17.066 un recurso de apelación ante un Tribunal de Comercio, formado por tres abogados ${ }^{72}$. Se estimó generalmente que

${ }^{68} \mathrm{El}$ informe favorable del Consejo de Defensa del Estado era necesario para la regularidad de la expropiación, tal como lo exigía el artículo $5^{\circ}$ del Decreto Ley 520.

${ }^{69}$ Novoa Monreal, E., Los Resquicios, Op. Cit. p. 81.

${ }^{70}$ El Decreto Ley 520 disponía que quedaban sujetos al control de la Superintendencia de Abastecimientos y Precios, que posteriormente será DIRINCO, la producción, manufactura, distribución y transporte de los artículos que el Presidente de la República declare de primera necesidad o de uso o consumo habitual, permitiendo que la autoridad pueda requisar mercaderías en caso de acaparamiento, ocultamiento o negación de ventas con fines de especulación o sin fin justificado, las que luego vendería por cuenta de sus dueños. El decreto reglamentario 338 del Decreto Ley 520 señala, además, que la requisición puede referirse también a establecimientos, explotaciones y servicios que atienden las necesidades económicas de todos los habitantes del país. La requisición no es una institución de efectos permanentes y no transfiere el dominio del bien requisado, sólo puede la autoridad incautarlos en cumplimiento de los fines señalados. Por ello, más que para lograr el fin de conseguir configurar el área de propiedad social, su uso más bien respondería a la actitud agresiva del gremio empresarial de acaparar y negarse a producir. No obstante, parece que en los hechos sí se le utilizó con estos fines. El punto es evidentemente discutible.

${ }^{71} \mathrm{La}$ Contraloría en dictamen 43.315 de 1971 hace la distinción diciendo que la primera tiene por fin permitir la fácil y oportuna afluencia de productos al mercado consumidor. La segunda sería una sanción por hechos de acaparamiento o especulación.

72 Designados uno por el Ministro de Economía, y los otros dos por el Consejo General del Registro Nacional de Comerciantes y por el Consejo de Defensa del Estado respectivamente. La verdad es que estaba compuesto tanto por alguien del gremio y de un organismo considerado políticamente neutro y altamente valorado por su capacidad técnica, el Consejo de Defensa del Estado, además del representante del gobierno. Era un tribunal imparcial y técnicamente idóneo como para satisfacer los requerimientos de juridicidad. 
este recurso sólo se podía conceder en el caso de una requisición como sanción, y no como medio de regulación económica, pues en este caso el criterio de la administración debía considerarse soberano ${ }^{73}$. En este sentido, el Tribunal de Comercio no dio lugar al recurso de apelación interpuesto por Yarur, el propietario de la industria requisicionada. Los afectados recurrieron entonces de queja ante la Corte Suprema y ésta ordenó al tribunal de Comercio concederles el recurso de apelación. El gobierno de Allende señaló que no había lugar a la queja, pues el tribunal ad-quem, en este caso, era uno administrativo $^{74}$, que no formaba parte del poder judicial, y por ello no estaba sujeto a la superintendencia directiva, correccional y económica que la Constitución y el Código Orgánico de Tribunales otorgaban a la Corte Suprema, y que es la base del recurso de queja. El gobierno de Allende, mediante esta reacción, denunciaba que se estaba vulnerando la separación de poderes que establecía tanto la Constitución como el artículo 4 del Código Orgánico de Tribunales ${ }^{75}$.

Lo anterior tiene gran importancia, pues además de que tal recurso de la Corte Suprema comenzó a utilizarse para detener las requisiciones que se implementaban bajo aprobación del gobierno de Allende, también marcó el punto más álgido de discusión y descalificación entre el gobierno, como poder ejecutivo, y el poder judicial: el nodo era las atribuciones constitucionales de uno y otro poder, y la disputa no se detuvo sino con el golpe militar ${ }^{76}$. El incidente de la requisición Yarur terminó con manifestaciones callejeras contra la Corte Suprema ${ }^{77}$.

Por su parte, los empresarios empezaron a defenderse contra inminentes intervenciones del poder ejecutivo a través de medidas precautorias. así, el formalismo jurídico del gobierno de Allende fue contestado con más formalismo jurídico. Sus mismos partidarios empezaron a hablar, ahora ellos, de "triquiñuelas legales"78.

También la Contraloría, pese a los informes favorables del Consejo de Defensa del Estado, comenzó a negar la toma de razón para los decretos que eran tramitados: se acusaba al gobierno de Allende de usar más resquicios legales cuando ocupaba el

${ }^{73}$ Novoa Monreal, Eduardo, ¿Vía Legal al Socialismo? (El caso Chileno), Editorial Jurídica Venezolana, Caracas, 1978, p. 105.

${ }^{74}$ Hacemos notar que no era disputa de la doctrina administrativista de aquellos años si los tribunales ordinarios podían tener competencia en asuntos administrativos. La Constitución de 1925 ordenaba la creación de Tribunales Administrativos cuya organización y atribuciones correspondía a la ley. Ésta nunca se dictó, pero en general se entendía que pese a existir un vacío, no le correspondía a los tribunales ordinarios, para no vulnerar la separación de poderes, interferir en estos asuntos. La doctrina jurídica más prestigiosa, como Silva Cimma, optaba por esta tendencia, a la que se llamaba "autonómica". El contencioso administrativo debía ser independiente del Poder Judicial. La Corte razonó en contrario. Vergara Blanco, Alejandro, "Esquema del contencioso administrativo: su tendencia hacia un modelo mixto y situación actual del recurso de protección", Litigación Pública, colección Estudios de Derecho Público, Primer Seminario de Litigación Pública, Universidad de los Andes, Abeledo Perrot-Thomson Reuters, Santiago, 2011, p. 37-63.

75 Artículo $4^{\circ}$ : Es prohibido al Poder Judicial mezclarse en las atribuciones de otros poderes públicos y en general ejercer otras funciones que las determinadas en los artículos precedentes.

76 Novoa Monreal, E., ¿ Via Legal al socialismo?, Op. Cit. p. 106.

77 Brahm G., E., "La perversión", Op. Cit., p. 342.

78 Villalonga, C., Revolución y Ley, Op. Cit., p. 133. 
decreto de insistencia (aunque muy importante, analizar el actuar de la Contraloría respecto de los decretos aprobados por el Consejo de Defensa del Estado requiere de un trabajo mayor que no podemos desarrollar aquî).

En definitiva, a través de la publicidad dada a estas disputas, se puso a vista del país al gobierno de Allende como trasgresor de la ley, aunque esto significara apartarse de las interpretaciones jurídicas que se habían sostenido por años en distintos gobiernos.

\section{Conclusiones}

Al concluir el año de 1971, Eduardo Novoa comprendió que los antagonismos que se estaban dejando ver a raíz de la aplicación de los resquicios legales hacían inviable el esfuerzo de adelantar el cumplimiento del programa a través de éstos. El costo político del gobierno era muy alto pues, aunque con muy malas razones, un sector muy influyente del país lograba, con su organización, medios y recursos, penetrar en el ciudadano chileno común que no estaba comprometido con el programa de la izquierda.

La ocasión para que los dirigentes y líderes políticos del gobierno de Allende comprendieran esta constatación fue la publicación del artículo "El difícil camino de la legalidad", que da título a este trabajo. Es un artículo inteligente y de gran valor.

Entre las cosas más lúcidas que aporta ese artículo está el convencimiento de que la vetusta legislación chilena debía ser tenida en cuenta, así como los principios que la inspiraban, debido a la gran importancia que le asignaban a los tribunales, demás organismos jurídicos y escuelas formadoras de abogados. Ésas son las teorías aceptadas uniformemente por los profesionales del derecho en Chile. Si bien, como señalara Novoa, existía una colisión entre principios distintos y contradictorios, de nada servía subrayar tal planteamiento teórico si los órganos institucionales a cargo del derecho se ponían espontáneamente de parte de la ideología burguesa ${ }^{79}$.

Muy confiados en las armas que les brindaba el positivismo jurídico ${ }^{80}$, los teóricos del gobierno y de los resquicios legales olvidaron la gran complejidad de lo que, en palabras de Bourdieu, es el campo jurídico. Las últimas conclusiones de Novoa nos acercan a algunas fuertes advertencias de Bourdieu, quien dice:

"los productores de leyes, reglas y reglamentos deben contar siempre con la reacciones, y a veces resistencia, de toda la corporación jurídica, particularmente de los expertos judiciales (abogados, notarios) que (...) pueden poner toda su capacidad jurídica al servicio de los intereses de categorías de clientes y organizar infinitas estrategias gracias a las cuales familias o empresas pueden anular los efectos de la ley"

\footnotetext{
${ }_{79}$ Novoa Monreal, Eduardo, "El difícil camino de la legalidad", Revista de la Universidad Técnica del Estado, Santiago, n ${ }^{\circ}$, 1972, p. 25.

${ }^{80}$ Garcés, J., El Estado, Op. Cit., p. 231.

81 Bourdieu, Pierre, Poder derecho y clases sociales, Descleé Brouwer, Bilbao, 2000, p. 176.
} 
Esto también vale para los jueces. Todo el que conozca la gran importancia que el positivismo moderno atribuye a la interpretación del derecho, sabe que toda norma legal es un marco abierto a varias posibilidades de interpretación ("textura abierta" del derecho lo llama Hart) y que, además de un elemento cognoscitivo hay en él un elemento volitivo ${ }^{82}$. Este elemento tiene que ver con las motivaciones del intérprete (sea, en nuestro caso, un abogado corporativo que además es profesor, o bien un magistrado ligado por amistad o nacimiento a la elite). Por lo tanto, las interpretaciones posibles tienen que ver con las concepciones políticas y morales del juez o intérprete. Evidentemente este espacio indeterminado no alcanzaría a violentar el Estado de Derecho, dice Hart. Pero, se nos advierte, desde un principio las ideas políticas y morales existen en la interpretación del derecho. Y su presencia no se debe descuidar.

Marx advirtió hace mucho tiempo ya: "el derecho no puede jamás estar a un nivel sobre la forma económica de la sociedad y su correspondiente desarrollo cultural"83. Finalmente, Novoa llega a igual conclusión al decir sobre la situación a que nos hemos referido: "Los sistemas jurídicos no han sido previstos para tensiones tan extremas" 84 .

Vemos ahora más claramente cuán alejada está la estrategia de los resquicios legales de una aplicación marxista del derecho. Tal vez la labor de los profesionales del derecho, en un verdadero uso alternativo ${ }^{85}$ y revolucionario de éste, es comenzar por desenmascarar el carácter ideológico de la pretendida cientificidad o neutralidad del derecho, para luego defender de este modo los intereses de las clases subalternas dentro del propio campo jurídico. No podemos dejar de recordar, aún en condiciones históricas distintas, que los ejemplos de Italia y posteriormente de España son valiosos. Partiendo del artículo 3 de la Constitución Italiana ${ }^{86}$, muy similar a ciertas disposiciones del Estatuto de Garantías ${ }^{87}$ (que en líneas gruesas obliga al Estado a remover los obstáculos de orden económico y social que limitaran la igualdad de los ciudadanos), el

\footnotetext{
82 Squella, Agustín, Introducción al Derecho, Editorial Jurídica de Chile, Santiago, 2000, p. 454.

${ }^{83}$ Marx, Kart, Crítica al Programa de Gotha, Anteo, Buenos Aires, 1972, p. 33.

84 Novoa Monreal, E., Los resquicios, Op. Cit. p. 97.

85 Debemos entender como uso alternativo del derecho a un complejo de actitudes y de comprensión del fenómeno jurídico que adquieren su sentido más acabado en el intento de instrumentalizar el derecho como arma política, valiéndose para esto tanto de la difusión y denuncia como de herramientas teóricohermenéuticas, además de las político ideológicas.

86 Artículo 3: Todos los ciudadanos tendrán la misma dignidad social y serán iguales ante la ley, sin distinción de sexo, raza, lengua, religión, opiniones políticas ni circunstancias personales y sociales. Constituye obligación de la República suprimir los obstáculos de orden económico y social que, limitando de hecho la libertad y la igualdad de los ciudadanos que impiden el pleno desarrollo de la persona humana y la participación efectiva de todos los trabajadores en la organización política, económica y social del país.

87 Se agrega al artículo 10 el 16, que en su inciso $1^{\circ}$ dice: El derecho a participar activamente en la vida social, cultural, cívica, política y económica con el objeto de lograr el pleno desarrollo de la persona humana y su incorporación efectiva a la comunidad nacional. El Estado deberá remover los obstáculos que limiten, en el hecho, la libertad e igualdad de las personas y grupos, y garantizará y promoverá su acceso a todos los niveles de la educación y la cultura y a los servicios necesarios para conseguir esos objetivos, a través de los sistemas e instituciones que señale la ley.
} 
grupo de jueces Magistratura Democrática ${ }^{88}$ (en sus inicios) lograron, interpretando el derecho, desarrollar en el propio campo jurídico posiciones de avanzada en términos políticos, dándole efectividad a los derechos constitucionales.

Sin duda el tiempo jugó en contra de esta maduración para el caso chileno, y personalmente creo que se podría haber producido un fenómeno similar al italiano, dadas las relaciones existentes entre organismos como CEREN y CESO con figuras de la Magistratura Democrática, que incluso llevaron a convenios de colaboración académica y a la realización de seminarios conjuntos ${ }^{89}$. Pero ésas son mis especulaciones. La verdad es que la fuerza puede más que la razón y si bien en el plano lógico, racional y civilizado, los resquicios legales eran derecho y la estrategia positivista de Novoa es inobjetable, aquello no condujo al socialismo y lo peor, no detuvo el golpe militar. Al contrario, como hemos dicho, sirvió de excusa para éste. Kennedy, siguiendo a Gramsci, dice que los juristas y los jueces son los intelectuales encargados de decidir qué normas son válidas, lo que es parte importantísima de la hegemonía. El pensamiento jurídico y el actuar de los operadores jurídicos, con su prestigio y proclama de universalidad y racionalidad, tienen un importante papel en el mantenimiento de la hegemonía de la clase dominante ${ }^{90}$. El caso chileno se compara al de Alemania, en el que los jueces y juristas, aludiendo a una supuesta defensa al Estado de Derecho, terminan por manipular la democracia constitucional, allanando el advenimiento de regimenes autoritarios ${ }^{91}$. Eso queda muy de manifiesto en sus interpretaciones intencionadas del derecho contra el gobierno.

Sintéticamente, los resquicios legales fueron escasamente usados para el fin deseado, no sirvieron para expropiar, sí para intervenir y requisar, lo cual no contribuyó a formar el Área de Propiedad Social ${ }^{92}$. A través de este método fracasó el plan de movilizar a las masas en su ascensión al poder: al no permitir la confirmación del Área de Propiedad Social y en cambio, al facilitar la imputación de ilegalidad por quiénes tenían la facultad de decidir qué era lo legal, definitivamente no se logró constituir las mayorías aplastantes que se buscaban.

\footnotetext{
88 Magistratura Democrática fue (y es aún) una asociación de jueces italianos que surgió en la Italia PostFascista al amparo de una asociación mayor, la UMI (Unión de Magistrados Italianos), que en un principio se definió como progresista y centraba su ideario en la responsabilidad política del juez de dar efectividad a los principios constitucionales. Posteriormente radicalizó su postura, por motivos propios de la vida política italiana, y pasó, entre otras cosas, a sostener la necesidad de usar la legalidad para favorecer a los sectores explotados y débiles de la sociedad, reconociéndose como inspirados por el marxismo, y se asumen como parte del movimiento de clase. Destacan en este movimiento autores de la categoría de Salvatore Senese, Luigi Ferrajioli y Pietro Barcellona. Posteriormente el grupo se reformuló y ha tomado posiciones garantistas. ${ }^{89}$ Mulas, Andrea, "Las relaciones político-jurídicas entre Lelio Basso y el Ceren en los años de gobierno de la Unidad Popular", Revista Universum, Talca, vol. 1, n 20, 2005, p. 80 - 87.

${ }^{90}$ Kennedy, Duncan, "Antonio Gramsci and the legal System", ALSA forum, Boston, vol. 6, no 1, 1982, p. 35. http://duncankennedy.net, consultada el 17 de mayo de 2013.

${ }^{91}$ Maravall, Jose María, "The rule of law as political weapon," en Adam Przeworski (ed.), Democracy and the rule of law, Cambridge University Press, Cambridge, 2003, p. 276.

92 Novoa Monreal, E., Los Resquicios, Op. Cit. p. 103.
} 
Nuestro triste epílogo no puede dejar de mencionar el bando $\mathrm{n}^{\circ} 5$ de la Junta Militar. Durante los primeros días del Golpe, los bandos se dirigieron a tomar acciones contra saboteadores y neutralizar una posible respuesta de los partidarios del gobierno. Pero el bando $\mathrm{n}^{\circ} 5$ es importante pues da las razones del Golpe, contiene sus justificaciones. Y si alguien quiere leerlo podrá ver que, en ese texto se afirma que la "partida de los insurrectos" se debió a que el gobierno de Salvador Allende "introducía artificialmente la lucha de clases", "quebrantaba los derechos fundamentales" y, además, "en sus actos recurrió al subterfugio de los resquicios legales, dejando así a las leyes en inejecución" ${ }^{3}$. No obstante lo anterior, y valga la paradoja, es el propio Augusto Pinochet quien se encarga de poner término a la discusión. Mediante Decreto Ley n 3.47794 (¿no era que los decretos leyes eran espurios?), texto misceláneo, se deroga el Decreto Ley 520 del año 1932. Recuérdese que no se puede derogar una ley que no haya estado vigente, como no se puede matar lo que nunca vivió.

El derecho no tiene que ver con la política, pero la política amparada en la fuerza, sin duda no tendrá reparos en quemar los libros de cualquier jurista vienés sin importar su venerable sabiduría.

\footnotetext{
${ }^{93}$ Urzúa, Germán, Manual de Derecho Constitucional, Editorial Jurídica de Chile, Santiago, 1991, p. 73.
}

${ }^{94}$ Novoa Monreal, E., Los resquicios, Op. Cit., p. 111. 


\section{Bibliografía}

Baño, Rodrigo y Flisfisch, Ángel, "Aspectos Institucionales en el colapso de la Unidad Popular y la Democracia Chilena", Documento de Trabajo, FLACSO-Chile, Santiago, no 342, 1987, 56 p.

Bergalli, Roberto, "Una ética absoluta y vital. Eduardo Novoa Monreal (1916-2006)", Nueva Doctrina Penal, Ediciones del puerto, Buenos Aires, 2006, n 2006/A, p. 10.005-10.014.

Bourdieu, Pierre, Poder derecho y clases sociales, Descleé Brouwer, Bilbao, 2000, 232 p.

Brahm García, Enrique, "La perversión de la cultura jurídica chilena durante el gobierno de la Unidad Popular. Resquicios legales y derecho de propiedad", Revista Chilena de Historia del Derecho, Santiago, no 18, 2000, p. 335-349.

Bravo, Bernardino, "Presidente y Estado de Derecho en Chile", Revista Derecho y Jurisprudencia, Santiago, T. XC, 1993, p. 63-89.

Cordero Quinzacara, Eduardo, "La Dogmática Constitucional de la Propiedad en el Derecho Chileno", Revista de Derecho, Santiago, vol. xix, no 1, Julio 2006, p. 125-148.

Corvalán, Luis, El Gobierno de Salvador Allende, LOM, Santiago, 2003, 366 p.

Ducci, Carlos, Derecho Civil, Parte General, Editorial Jurídica de Chile, Santiago, 2005, 448 p.

Garcés, Joán, El Estado y los Problemas Tácticos en el gobierno de Allende, Fondo de Cultura Económica, Madrid, 1974, 310 p.

González, Francisco Javier, Partido Democratacristiano, La lucha por definirse, Instituto de Estudios Generales, Valparaíso, 1989, 245 p.

Kennedy, Duncan, "Antonio Gramsci and the legal System", ALSA forum, Boston, Vol. VI, $\mathrm{n}^{\mathrm{o}} 1, \quad 1982$, p. 32-37, http://duncankennedy.net, consultado el 17 de mayo de 2013.

Loveman, Brian y Lira, Elizabeth, Las Ardientes Cenizas del olvido, Via Chilena de reconciliación Política, 1932-1994, LOM, Santiago, 2000, 601 p.

Maravall, José María, "The rule of law as political weapon", en Adam Przeworski (ed.), Democracy and the rule of law, Cambridge University Press, Cambridge, 2003, p. 261-301.

Marx, Karl. Crítica al Programa de Gotha, Anteo, Buenos Aires, 1972, 126 p.

Mulas, Andrea, "Las relaciones políticojurídicas entre Lelio Basso y el CEREN en los años de gobierno de la Unidad Popular", Revista Uniwersum, Talca, vol. 1, no 20, 2005, p. 80-87.

Novoa Monreal, Eduardo, Los resquicios legales. Un ejercicio de lógica jurídica, Editorial Bat, Santiago, 1992, 165 p.

¿Via Legal al Socialismo? (El caso Chileno), Editorial Jurídica Venezolana, Caracas, 1978, 136 p.

"El difícil camino de la legalidad", Revista de la Universidad Técnica del Estado, Santiago, $n^{\circ}$ 7, 1972, p. 9-34.

El Derecho como obstáculo al cambio social, Editorial siglo XX, Ciudad de México, 1975, 255 p.

"Vías legales para avanzar al socialismo", Revista de Derecho Económico, Santiago, no 33 y 34, 1971, p. 27-40.

"La crisis del sistema legal chileno", Revista Mensaje, Santiago, no 134, 1964, p. 559-556.

Elementos para una crítica y desmitificación del derecho, Ediar, Buenos Aires, 1985, $250 \mathrm{p}$.

"La nacionalización del cobre: aspectos jurídicos", Revista Mensaje, Santiago, $\mathrm{n}^{\mathrm{o}} 204,1971$, p. 513-515.

"Carta al candidato presidencial Dr. Salvador Allende", en Novoa Monreal, Eduardo, Obras escogidas. Una crítica al derecho tradicional, Centro de Estudios Políticos Latinoamericanos Simón Bolívar, Santiago, 1993, p. 409-411. 
Pacheco, Máximo, Teoría del Derecho, Editorial Jurídica de Chile, Santiago, 1994, 865 p.

Sierra Iribarne, Lucas, "Derecho, cambio social y juristas en Chile: De la estridencia de los 60 al silencio de hoy", Documento de trabajo, SELA Yale University, 15p. http://digitalcommons.law.yale.edu/cgi/viewcont ent.cgi?article $=1012 \&$ context $=y l s$ sela, , consultado el 17 de mayo de 2013.

Squella, Agustín, Introducción al Derecho, Editorial Jurídica de Chile, Santiago, 2000, 576 p.

Soto Kloss, Eduardo, "La Competencia contencioso administrativa de los tribunales ordinarios de justicia", Revista Chilena de Derecho, Santiago, Vol. 1, 1974, p. 349-359.
Sousa Santos, Boaventura, Crítica de la razón indolente, Bilbao, Descleé Brouwer, 2003, 481 p.

Vergara Blanco, Alejandro, "Esquema del contencioso administrativo: su tendencia hacia un modelo mixto y situación actual del recurso de protección", Litigación Pública, colección Estudios de Derecho Público, Primer Seminario de Litigación Pública, Universidad de los Andes, Abeledo Perrot-Thomson Reuters Editores, Santiago, 2011, p. 37-63.

Villalonga, Cristian, Revolución y Ley. La Teoría Crítica del Derecho en Eduardo Novoa Monreal, Editorial Globo, Santiago, 2008, 240 p.

Urzúa, Germán, Manual de Derecho Constitucional, Editorial Jurídica de Chile, Santiago, 1991, 434 p. 